\title{
EFFECT OF BABY MASSAGE ON BABY WEIGHT AGED 0-6 MONTHS
}

\author{
Deviana Ramdhawati Hasanah'1), Etin Rohmatin²), Herni Kurnia ${ }^{3)}$ \\ devianasheldon@gmail.com \\ Health Polytechnic of Tasikmalaya \\ Midwifery Department
}

\begin{abstract}
Background : Infancy is a golden period as well as a critical period of development. It is said to be a critical period because at this time the baby is very sensitive to the environment and is said to be a golden period because the time is very short and cannot be repeated again. Stimulation in infancy is very necessary to stimulate growth and development. Baby massage is an activity carried out by parents or caregivers of the baby as an act of stimulating the growth and development of the baby

Purpose : The aim of the study is to determine the effect of baby massage on infants' weight aged 0-6 months in working area of Cibeureum Public Health Center in Tasikmalaya

Method : Pre-experimental design with one group pretest-posttest design approach was applied. Total respondents were 29 infants, obtained using purposive sampling technique. Data analysis used univariate analysis and bivariate analysis with the Spearman correlation test.

Results : The results showed, $\mathrm{p}$ value was 0.05 which was considered as more than $\alpha$ $(0,000)$. It can be stated that Null hypotheses was accepted, there was no effect of baby massage on infants' weight.

Conclusions : This study did not support the effect of baby massage towards babies' weight. However, baby massage is remain suggested in order to improve emotional relationship between parent and the baby. Future studies need to be conducted regarding baby massage combined with other treatment that might help infants' growth

\section{Keywords : Baby massage, baby weight \\ 1) Student of DIV Midwifery Study Program, Health Polytechnic of Tasikmalaya \\ 2,3) Lecturer at the Midwifery Department, Health Polytechnic of Tasikmalaya}

Background. One of the growth's manifestations is weight. Age of 1-3 months is a period of rapid growth, so it is necessary to maintain the baby's weight at this period of age. Body weight is greatly influenced by genetics, environment, health level, nutritional status, and physical exercise. There are many factors that influence infants growth and development, needing to be strived to maintain a normal body weight according to age, among others, by: meeting the nutritional needs of babies both in quantity and quality,

maintaining a condusive environment by making a comfortable living environment and good sanitation, maintaining the health of infants by immunizations and routine visit to health services, and finally providing stimulus. The stimulus given is tactile stimulation. Baby massage is considered as tactile stimuli because the massage can stimulate the muscles, bones and organ systems to function optimally. Baby massage is the oldest and most popular touch therapy known. Baby massage has long been practiced
\end{abstract}


throughout the world, including in Indonesia, passed down from generation to generation. Touching and massaging the baby after birth can assure ongoing body contact which can maintain a secure feeling of the baby. (Rio Artiani, 2009).

According to a Preliminary Study at the Cibeureum Public Health Center in Tasikmalaya, the number of infants aged 0-6 months in January-March 2019 from 9 villages in the working area of the Cibeureum Public Health Center that experienced constant weight weighing (stunted growth) were 180 infants. While data from Cibeureum Public Health Center in 2019, the coverage of exclusive breastfeeding were 522 babies.

Purpose. The aim of the study is to determine the effect of baby massage on infants' weight aged $0-6$ months in working area of Cibeureum Public Health Center in Tasikmalaya.

Methods. This is an experimental research with pre-experimental methods, aimed to determine the effect of baby massage on infants' weight aged 0-6 months in Cibeureum Public Health Center, Tasikmalaya. The design is one group pretest-posttest design, there was a pretest before and a posttest after being given the treatment. (Notoatmodjo, 2010).

The form of this research is as follows :

\section{Figure 3.1 Research Design}

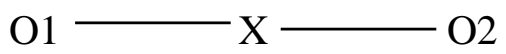

This research was conducted in January - March 2019 at the Cibeureum Public Health Center in Tasikmalaya. The population in this study were 180 infants whose growth was affected (fixed weight weighing) in the working area of the Cibeureum Public Health Center in Tasikmalaya from January to
March 2019. The sample in this study was infants aged 0-6 months who met the following criteria:

a. Inclusion Criteria:

1) Babies 0-6 months with exclusive breastfeeding

2) The weight graph is flat or downward cutting the growth line below it or the weight gain is less than the KBM on the KMS KIA book with the status $\mathrm{T}=$ Fixed

3) Consecutive weighing does not rise or BGM

b. Exclusion Criteria : Sick baby

Research Variable :

a. Independent Variables : Baby Massage

b. Dependent Variables : Baby's weight

Result and Discussion. The results of the study included a description of baby's weight data before the baby massage (pre-test), a description of the baby's weight data after the baby massage (post-test) and the effect of baby massage on the infant's weight.

The results are presented in two levels of analysis, namely univariate analysis describing the descriptive of each research variable and bivariate analysis describing the effect of baby massage on infant weight based on data before and after treatment.

The results are presented in two levels of analysis, namely univariate analysis describing the descriptive of each research variable and bivariate analysis describing the effect of baby massage on infant weight based on data before and after treatment

1. Univariat Analysis

Table 1. Baby's Weight Before Baby Massage

\begin{tabular}{cccc}
\hline No & $\begin{array}{c}\text { Weight } \\
\text { (gram) }\end{array}$ & $\mathbf{f}$ & $\%$ \\
\hline 1 & $<3000$ & 2 & 6,9 \\
2 & $3000-6000$ & 18 & 62,1 \\
3 & $>6000$ & 9 & 31 \\
\hline & Total & $\mathbf{2 9}$ & $\mathbf{1 0 0}$ \\
\hline
\end{tabular}


Table 1. Mostly, the baby's weight before baby massage is in the category of 3000-6000 grams $=18$ babies $(62.1 \%)$.

Table 2. Baby's Weight After Baby

\begin{tabular}{cccc} 
Massage & \\
\hline No & $\begin{array}{l}\text { Weight } \\
\text { (gram) }\end{array}$ & $\mathbf{f}$ & $\mathbf{\%}$ \\
\hline 1 & $<3000$ & - & - \\
2 & $3000-6000$ & 13 & 44,8 \\
3 & $>6000$ & 16 & 55,2 \\
\hline & Total & $\mathbf{2 9}$ & $\mathbf{1 0 0}$ \\
\hline
\end{tabular}

Table 2. shows that most of the baby's weight after the baby massage is $>6000$ grams category, as many as 16 babies $(55.2 \%)$.

\section{Bivariat Analysis}

Table 3. The Effect of Baby Massage on

\begin{tabular}{cccc}
\multicolumn{3}{c}{ Baby's Weight } \\
\hline No & Category & f & $\%$ \\
\hline 1 & Rising & 2 & 6,9 \\
2 & Not Rising & 27 & 93,1 \\
\hline & Total & $\mathbf{2 9}$ & $\mathbf{1 0 0}$
\end{tabular}

It can be inferred from table 3 . that the majority of babies did not experience weight gain after baby massage, which is as many as 27 babies $(93.1 \%)$. Spearman rank test resulted in pvalue more than $\alpha(0.000<0.05)$, it was stated there was no effect of baby massage on the baby's weight.

The results of this study differ from the study conducted by Claudia (2017), which reveled that there is an effect of infant massage on weight changes in infants aged 6-12 months. This is not as stated by Riksani (2012), that babies who are massaged regularly from birth often gain weight faster than other babies who are not massaged because massage stimulates the production of growth hormones.

Conclusion and Suggestions. Based on the results of the research on the effect of baby massage on infant's weight aged 0-6 months in the Cibeureum Health Center in Tasikmalaya in 2019 there is no effect of baby massage on the weight of infants. It is recommended for future researchers to develop research on infant massage with a control group so that it will clearly illustrate the effect of baby massage on the growth of infants aged 0-6 months.

\section{References}

Artiani, Ria. (2009). Efektititas Frekuensi Pijat Bayi Terhadap Perkembangan Bayi. Jakarta : Fakultas Kedokteran Universitas Indonesia

Badan Bayi dengan Status Tetap Tahun 2018

Dewi, Siska. (2011). Pijat dan Asupan Gizi Tepat Untuk Melejitkan Tumbuh Kembang Bayi. Yogyakarta : Pustaka Baru Press

Griya Sehat Indonesia. (2017). Baby Spa Training (Baby Massage, Baby Swim, And Baby Gym)

Heath dan Bainbridge. (2007). Baby Massage. Jakarta : Dian Rakyat

Hidayat, Aziz Alimul. (2014). Metode Penelitian Kebidanan Dan Teknik Analisis Data. Jakarta : Salemba Medika

Kemenkes RI. (2014). Situasi dan Analisis ASI Eksklusif. Indonesia : Infodatin

Khomsan, A dan Sitti R. (2008). 50 Menu Sehat untuk Tumbuh Kembang Anak Usia 6-24 Bulan. Jakarta : PT Agromedia Pustaka

Notoatmodjo, Soekidjo. (2010). Metodologi Penelitian Kesehatan. Jakarta : PT. Rineka Cipta

Nur Wafi, Muslihatun. (2011). Asuhan Neonatus Bayi dan Balita. Yogyakarta : Fitramaya

Ruslina, Suradi. (2010). Manfaat ASI dan Menyusui. Jakarta : Fakultas Kedokteran Universitas Indonesia 
Soetjiningsih. (2012). Tumbuh Kembang Anak. Jakarta: Penerbit Buku Kedokteran EGC

Soetjiningsih. (2012). Tumbuh Kembang Anak. Jakarta : Penerbit Buku Kedokteran EGC

Sugiyono. (2011). Statistik Untuk Penelitian. Bandung : Alfabeta

Tritton. (2009). Memijat Bayi Yang Menyejukkan. Jakarta : Ladang Pustaka
Yuliana, A, Suharto, A dan Handayani T.E. (2013). Perbedaan berat badan bayi usia 3-5 bulan yang dipijat dan tidak dipijat di Kelurahan Tawanganom Kecamatan Magetan tahun 2013. Jurnal Penelitian Kesehatan Suara Forikes. Volume 4. Nomor 4.

WHO. (2017). 10th Facts On Breast Feeding.

Dunia

Infointernasional 